\title{
Article \\ Effects of Different Organic Soil Amendments on Nitrogen Nutrition and Yield of Organic Greenhouse Tomato Crop
}

\author{
Anastasios Gatsios ${ }^{1}\left(\mathbb{D}\right.$, Georgia Ntatsi ${ }^{1}{ }^{\mathbb{D}}$, Dionisios Yfantopoulos ${ }^{1}$, Penelope Baltzoi ${ }^{2}$, Ioannis C. Karapanos ${ }^{1}$, \\ Ioannis Tsirogiannis ${ }^{2}\left(\mathbb{D}\right.$, Georgios Patakioutas ${ }^{2}$ and Dimitrios Savvas $1, * \mathbb{C}$ \\ 1 Laboratory of Vegetable Production, Department of Crop Science, Agricultural University of Athens, \\ 11855 Athens, Greece; gatsios@aua.gr (A.G.); ntatsi@aua.gr (G.N.); yfantopoulos@aua.gr (D.Y.); \\ karapanos@aua.gr (I.C.K.) \\ 2 School of Department of Agricultural Technology, University of Ioannina, Kostakii Arta, 47100 Arta, Greece; \\ pinelbalt@uoi.gr (P.B.); itsirog@uoi.gr (I.T.); gpatakiu@uoi.gr (G.P.) \\ * Correspondence: dsavvas@aua.gr; Tel.: +30-210-5294510
}

check for

updates

Citation: Gatsios, A.; Ntatsi, G.; Yfantopoulos, D.; Baltzoi, P.;

Karapanos, I.C.; Tsirogiannis, I.;

Patakioutas, G.; Savvas, D. Effects of Different Organic Soil Amendments on Nitrogen Nutrition and Yield of Organic Greenhouse Tomato Crop. Nitrogen 2021, 2, 347-358. https:// doi.org/10.3390/nitrogen2030024

Academic Editor: Germán Tortosa

Received: 13 July 2021

Accepted: 24 August 2021

Published: 26 August 2021

Publisher's Note: MDPI stays neutral with regard to jurisdictional claims in published maps and institutional affiliations.

Copyright: (c) 2021 by the authors. Licensee MDPI, Basel, Switzerland. This article is an open access article distributed under the terms and conditions of the Creative Commons Attribution (CC BY) license (https:// creativecommons.org/licenses/by/ $4.0 /)$.

\begin{abstract}
Manure is a common source of nitrogen $(\mathrm{N})$ in organic farming. However, manure is not always easily available, while the maximum $\mathrm{N}$ amount added as animal manure in organic agriculture is restricted by EU regulations. The present study was designed to test whether green manuring with a warm-season legume and intercropping with a cold-season legume can substitute farm-yard manure or compost as $\mathrm{N}$ sources in organic greenhouse tomato crops. To test this hypothesis, a winterspring (WS) tomato crop was installed in February following the incorporation of crop residues of an autumn-winter (AW) tomato crop intercropped with faba bean, which had been fertilized with cowpea residues as green manure. This treatment, henceforth termed legume treatment (LT), was compared with the use of compost or manure as an $\mathrm{N}$ fertilization source in both tomato crops. In addition, a combination of compost and LT was also used as a fourth treatment. The results showed that green manuring with legumes and particularly cowpea can contribute a significant amount of $\mathrm{N}$ to the following organic tomato crop, through the biological fixation process. Nevertheless, legumes as green manure, or compost, or their combination cannot efficiently replace farmyard manure as an $\mathrm{N}$ fertilization source. Compost exhibited a slow mineralization course.
\end{abstract}

Keywords: Solanum lycopersicum; cowpea; faba bean; rhizobia; green manure; intercrop; nitrogen; farmyard manure; compost

\section{Introduction}

Organic farming has grown significantly over the last two decades. According to Willer and Lernoud [1], during this period the cultivated organic area almost increased sevenfold, while the share of organic cultivation in the total cultivated area increased fivefold. The main reasons for this increase were, on the one hand, the concern of many people about the impact of conventional agriculture on their health and the environment [2], and especially on the pesticide residues in food [3], and on the other hand, the decision of many farmers to turn to organic farming. This can be ascribed especially to the fact that the growers have seen an impasse in conventional cultivation due to soil degradation, reduced soil fertility, and the evolution of pesticide resistance. If we add to this the fact that public awareness about greenhouse gas emissions and climate change has significantly risen in the last decades, it is easy to justify this increased interest in organic farming.

However, organic farming has many limitations imposed by national or international regulations, the implementation of which is controlled by public or private certification bodies. Thus, the application of synthetic chemicals is prohibited for both plant protection and fertilization purposes [4] and only environment-friendly practices, such as crop rotation, enhancement of soil fertility through biological processes, composting, and beneficial biota can be deployed to maintain soil fertility and control pathogens and pests $[4,5]$. 
Nitrogen $(\mathrm{N})$ availability is critical for plant performance in both conventional and biological farming systems [6,7]. However, in many countries and throughout EU, the use of inorganic $\mathrm{N}$, not only synthetic but also of mineral origin, is prohibited in organic farming. Thus, sufficient availability of $\mathrm{N}$ becomes the most critical factor for yield performance in organic crops. Consequently, adequate supply of $\mathrm{N}$ in organic crops is a primary concern for the economic success of this production system [8-10].

Farm-yard manure (FYM) is one of the most common organic amendments in organic plant production, both in highly intensive systems, which are more frequent in Northern and Central European countries, and in less intensive cropping systems found mainly in Mediterranean regions [11,12]. The total amount of livestock manure applied as fertilizer should provide $\mathrm{N}$ at amounts that do not exceed $170 \mathrm{~kg}$ of $\mathrm{N}$ per hectare according to the Commission Reg. (EC) No 889/2008 [13]. This amount is insufficient for greenhouse tomato crops, especially when production takes place year-round [14]. Furthermore, animal manure originating from factory farming systems is forbidden by the same regulation, while in some countries animal manure of organic farming origin is compulsory.

Compost is another main soil amendment in organic farming that successfully contributes to the soil structure maintenance and nutrient supply [15,16]. The most important factors that define the use of either compost or animal manure are the cost of the product, its quality, and its availability in the market. For example, compost from olive-mill wastes of high quality and low cost is easily available in the Mediterranean basin [17].

The use of legumes as green manure or intercrops can be an important source of $\mathrm{N}$ in organic agriculture $[18,19]$. Legumes, when cultivated as green manure, can supply a significant amount of $\mathrm{N}$ to subsequent organic tomato crops [20]. This is ascribed to their ability to fix $\mathrm{N}_{2}$ from the atmosphere through symbiotic relationships with rhizobia [18]. It is well documented that inoculation of the legume seeds with suitable rhizobia strains may result in increased nodulation, biological $\mathrm{N}$ fixation (BNF), and total biomass, especially if the legume species have not been cultivated before in the specific soil [12,21]. The use of green manure, although highly recommended in organic farming as reported explicitly in the EU Regulation, is rather difficult to be implemented in greenhouses compared to open-field crops, mainly due to economic reasons [11].

In the above context, the present study was designed to test the possibility of using legumes as green manuring and intercropping, as an alternative source of $\mathrm{N}$ in a greenhouse tomato crop grown according to organic farming practices. To address this question, cowpea was cultivated for green manuring during summer, while faba bean was cultivated as intercrop during autumn and winter by sowing between the tomato rows. Legume biomass was incorporated either alone or in combination with olive-mill waste compost and compared with FYM application in terms of its ability to provide inorganic $\mathrm{N}$ and enhance the yield of the next tomato crop, which was planted in February and terminated in June.

\section{Materials and Methods}

\subsection{Site and Plant Material}

An experiment was conducted to evaluate legume biomass, applied as green manuring and intercropping, alone or in combination with compost, as sources of $\mathrm{N}$ in organic tomato crop. The experiment was carried out in a commercial greenhouse located in Preveza, North-Western Greece ( $38^{\circ} 59^{\prime} 29.2^{\prime \prime} \mathrm{N} ; 20^{\circ} 45^{\prime} 36.1^{\prime \prime}$ E, 5 m.a.s.l.) from February 2018 to June 2018. The experimental tomato crop followed another organic tomato crop (preceding tomato crop), which was established on 2 August 2017 and terminated on 19 January 2018. The experiment was laid out as a randomized complete block design with four replicates and the plot size was $15 \mathrm{~m}^{2}$.

Four different fertilization treatments were applied in the experimental tomato crop (Table 1). In treatment $1(\mathrm{FYM})$, farmyard manure was applied at a rate of $50 \mathrm{t} \mathrm{ha}^{-1}$, which was considered the control treatment. The FYM was obtained from free-range cattle farming and contained $0.34 \% \mathrm{~N}, 0.15 \% \mathrm{P}$, and $0.48 \% \mathrm{~K}$. In treatment 2 (OMWC), only 
olive-mill waste compost, containing $1.26 \% \mathrm{~N}, 0.08 \% \mathrm{P}$, and $1.03 \% \mathrm{~K}$, was applied at a rate of $30 \mathrm{t} \mathrm{ha}^{-1}$. In treatment 3 (legume treatment: LT), cowpea (Vigna unguiculata (L) Walp.) was grown for 2 months during the summer and incorporated into the soil as green manure before establishment of the preceding tomato crop. In the same experimental plots, faba bean (Vicia faba L.) was cultivated as intercrop during the preceding tomato crop and the produced biomass was incorporated into the soil at crop termination. Finally, in treatment 4 (LT + OMWC), the same compost as in treatment 2 (OMWC) was applied in combination with the legumes used as green manure and intercrops in treatment 3 (LT).

Table 1. Description of the organic matter applied as organic fertilization source in each experimental treatment. FYM: farmyard manure; LT: legume treatment; OMWC: olive-mill waste compost.

\begin{tabular}{lll}
\hline No & Treatment & Description \\
\hline 1 & FYM & $\begin{array}{l}\text { Farmyard manure } 50 \mathrm{tha}^{-1} \text { (considered as control) } \\
\text { Olive-mill waste compost } 30 \mathrm{tha}^{-1}\end{array}$ \\
3 & OMWC & $\begin{array}{l}\text { Cowpea green manure before the preceding tomato crop } \\
\text { and faba bean intercropped with the preceding tomato crop } \\
\text { Cowpea green manure before the preceding tomato crop } \\
\text { and faba bean intercropped with the preceding tomato crop } \\
\text { plus olive-mill waste compost at a rate of } 30 \mathrm{tha}^{-1}\end{array}$ \\
\hline
\end{tabular}

Prior to their sowing, the seeds of cowpea were inoculated with a mix of Bradyrhizobium sp. VULI11, isolated from nodules of field-grown cowpea in Greece [22], whereas the seeds of faba bean were inoculated with a mix of Rhizobium sp. symbiovar (sv.) viciae, isolated from field-grown faba bean nodules in Greece [23]. Faba bean was sown between the tomato rows at a density of 10.67 seed $\mathrm{m}^{-2}, 85$ days after tomato transplanting. OMWC was applied at the same dose in treatment 4 as in treatment 2 (Table 1).

The experimental tomato crop was established on 9 February 2018 by planting grafted seedlings of the commercial hybrid 'Ekstasis F1' (Solanum lycopersicum L.). The commercial rootstock Maxifort F1 (S. lycopersicum $\times$ S. habrochaites) was used for grafting. The plant density was 2.13 plants $\mathrm{m}^{-2}$. The plants were cultivated following organic farming practices as specified in the EU Regulation (EC) No 889/2008 [13]. About 2.5 months after planting, the plants exhibited visible $\mathrm{N}$ deficiency symptoms in all treatments, albeit differing in the severity between treatments. Following standard commercial practices, this problem was addressed by applying a soluble organic $\mathrm{N}$ fertilizer containing $14 \% \mathrm{~N}$ in the form of amino acids via the drip irrigation system to all treatments. The organic $\mathrm{N}$ fertilizer was applied at four doses on April 25 and 29 and on May 2 and 6. The total amount of fertilizer applied was $16 \mathrm{~g} \mathrm{~m}^{-2}$, which provided $22.4 \mathrm{~kg} \mathrm{~N} \mathrm{ha}^{-1}$ to all treatments.

Climatic data, particularly air temperature and relative humidity, were automatically recorded on an hourly basis throughout the experimental period using suitable sensors and data loggers. Using this data, monthly averages of temperature (mean, maximum, minimum) and relative humidity (\%) were computed, which are presented in Table 2.

Table 2. Monthly averages of mean, maximum, and minimum daily temperatures $\left(T_{\operatorname{mean}}, T_{\max }\right.$, and $\mathrm{T}_{\text {min }}$, respectively) and relative humidity $\left(\mathrm{RH}_{\text {mean }}, \mathrm{RH}_{\max }\right.$, and $\mathrm{RH}_{\min }$, respectively) inside the greenhouse during the experimental period (February to June 2018).

\begin{tabular}{lcccccc}
\hline Month & $\mathbf{T}_{\text {mean }}$ & $\mathbf{T}_{\text {max }}$ & $\mathbf{T}_{\text {min }}$ & $\mathbf{R H}_{\text {mean }}$ & $\mathbf{R H}_{\text {max }}$ & $\mathbf{R H}_{\min }$ \\
\hline February 2018 & 13.1 & 15.7 & 11.6 & 87.3 & 94.4 & 79.2 \\
March 2018 & 14.7 & 20.9 & 10.5 & 82.9 & 93.1 & 75.1 \\
April 2018 & 19.3 & 27.5 & 13.6 & 78.1 & 89.4 & 68.3 \\
May 2018 & 23.1 & 31.0 & 18.1 & 70.8 & 87.1 & 55.3 \\
June 2018 & 25.5 & 33.1 & 20.1 & 62.3 & 84.6 & 33.9 \\
\hline
\end{tabular}




\subsection{Legume Biomass, $N$ Fixation and $N$ Accumulation}

The aboveground biomass of cowpea and faba bean was quantified before their incorporation to the soil by harvesting all the shoots from an area of $1 \mathrm{~m}^{2}$ in each plot center and determining their total fresh weight. Furthermore, a sub-sample of legume biomass was collected from each plot. After recording their fresh weight, the samples of legume biomass were oven-dried at $65^{\circ} \mathrm{C}$ to constant weight to determine their dry weight. The obtained fresh and dry weight data were used to determine the dry matter content of each sample, expressed as $\% w / w$. Subsequently, the dried samples were ground using a ball mill and sieved through a 40 mesh sieve. The obtained powder was used to determine total-N and carbon (C) concentrations through high temperature combustion using an elemental analyzer (Unicube, Elementaranalysensysteme GmbH, Hanau, Germany).

The $\mathrm{N}$ derived from the atmosphere (Ndfa) in the aboveground biomass of legumes was determined by applying a method based on the natural abundance of ${ }^{15} \mathrm{~N}$ in plant tissues relative to the air $[12,24,25]$. This method was described in detail in two previous papers [12,25]. Briefly, the $\delta^{15} \mathrm{~N}$ values were estimated in the Stable Isotope Facility of the University of California at Davis, as parts per thousand (\%) deviations relative to the nominated international standard of atmospheric $\mathrm{N}_{2}(0.3663 \%)$, using the following equation [26]:

$$
\delta^{15} \mathrm{~N}(\%)=\left(\frac{\text { atom } \%{ }^{15} \mathrm{Nsample}-0.3663}{0.3663}\right) \times 1000
$$

The obtained values of $\delta^{15} \mathrm{~N}(\%$ ) were subsequently used to determine the percentage of Ndfa by substituting them to the following equation suggested by Unkovich et al. [24]:

$$
\% \text { Ndfa }=\left(\frac{\delta^{15} \mathrm{~N} \text { of reference plant }-\delta^{15} \mathrm{~N} \text { of legume }}{\delta^{15} \mathrm{~N} \text { of reference plant }-\mathrm{B}}\right) \times 100
$$

where " $\mathrm{B}$ " is the $\delta^{15} \mathrm{~N}$ in shoots of cowpea or faba bean plants grown on an inert medium under complete $\mathrm{N}$ starvation throughout their life, which rendered them fully dependent on $\mathrm{N}_{2}$ fixation. The $\mathrm{B}$ values used in the current study were -1.61 for cowpea and -0.50 for faba bean, as suggested by Unkovich et al. [24]. The reference plant used in the current study to estimate their $\delta^{15} \mathrm{~N}$ values substituted in Equation (2) was the grass weed Digitaria sanguinalis (L.).

The \%Ndfa values obtained from Equation (2) were subsequently used to determine the total amount of biologically-fixed $\mathrm{N}_{2}$ by cowpea and faba bean per cultivated area unit $\left(\mathrm{BNF}, \mathrm{kg} \mathrm{ha}^{-1}\right.$ ) using the following equation [27]:

$$
\mathrm{BNF}=\frac{\mathrm{DB} \times \mathrm{Nt} \times \% \mathrm{Ndfa}}{100}
$$

where $\mathrm{DB}$ is the total dry biomass of the shoot, $\mathrm{Nt}$ is the concentration of total $\mathrm{N}(\% w / w)$ in the aboveground dry biomass of each legume, and \%Ndfa are the values obtained from Equation (2).

\subsection{Tomato Leaf Analysis}

To estimate the nutritional status of tomato, the leaf N, P, and K concentrations were estimated by collecting from each plot five young, fully expanded leaves of the same physiological age 75 days after transplanting. The leaves were washed with distilled water, chopped, and oven-dried at $65{ }^{\circ} \mathrm{C}$ until they reached a constant weight. Subsequently the leaf samples were powdered using a ball mill and passed through a 40 mesh sieve. To extract $\mathrm{K}$ and $\mathrm{P}, 0.5 \mathrm{~g}$ of powdered material was burned in a muffle furnace at $550{ }^{\circ} \mathrm{C}$ for $5 \mathrm{~h}$, and the obtained ash was dissolved in $1 \mathrm{~N} \mathrm{HCl}$. Phosphorus $(\mathrm{P})$ was measured photometrically as phosphomolybdate blue complex at $880 \mathrm{~nm}$ using a spectrophotometer (U-2000, Hitachi, Tokyo, Japan). Potassium (K) was determined through flame photometry using a Sherwood Model 410 instrument (Cambridge, UK). Another $0.5 \mathrm{~g}$ of powdered leaf 
material was used to determine the concentrations of organic $\mathrm{C}$ and total $\mathrm{N}$ in leaves using the same instrument and procedures as described above for the legume crops.

\subsection{Soil Analysis}

At five sampling dates during the experiment, soil samples were collected from the central square of each plot (dimensions $2 \times 2.5 \mathrm{~m}$ ). More specifically, soil samples were collected before incorporation of the organic matter to the ground, at 27, 57, and 92 days after organic matter incorporation to the soil and at termination of the tomato crop. The soil sample of each plot was obtained by collecting and mixing five soil cores weighing about $400 \mathrm{~g}$ from the root zone of five plants at a depth of 0-20 cm. Samples were prepared as described by Miller et al. [28] and analyzed to determine the total$\mathrm{N}, \mathrm{NO}_{3}-\mathrm{N}, \mathrm{NH}_{4}-\mathrm{N}$, and plant-available $\mathrm{P}$ and $\mathrm{K}$ concentrations in the soil. Total $\mathrm{N}$ in soil samples was determined by applying high temperature combustion using the same elemental analyzer as for leaf mineral analysis. Mineral $\mathrm{N}\left(\mathrm{N}-\mathrm{min}\right.$, i.e., $\left.\mathrm{NO}_{3}-\mathrm{N}+\mathrm{NH}_{4}-\mathrm{N}\right)$ was extracted from the soil samples using a $1 \mathrm{M} \mathrm{KCl}$ solution, as described by Keeney and Nelson [29]. The $\mathrm{NO}_{3}{ }^{-}$concentrations in the sample extracts were determined by applying the Copperized Cadmium Reduction Method to reduce $\mathrm{NO}_{3}{ }^{-}$to $\mathrm{NO}_{2}{ }^{-}$and photometrically measuring the $\mathrm{NO}_{2}{ }^{-}$concentration at $540 \mathrm{~nm}$ after its conversion to a diazo-complex (Griess-Ilosvay procedure) [29]. The $\mathrm{NH}_{4}{ }^{+}$concentration was measured photometrically at $630 \mathrm{~nm}$ by applying the indophenol blue method [29]. Plant-available phosphorus was determined using the Olsen method [30] and quantified photometrically as phosphomolybdate blue complex at $680 \mathrm{~nm}$ [31]. The photometric determinations of $\mathrm{NO}_{3}{ }^{-}, \mathrm{NH}_{4}{ }^{+}$, and $\mathrm{P}$ were performed using a Spectronic Helios spectrophotometer (Thermo Electron Corporation, Mercers Row, Cambridge, UK). Exchangeable soil K was determined using a flame photometer (Sherwood Model 420, Sherwood Scientific, Cambridge, UK) following extraction with an ammonium acetate solution.

\subsection{Tomato Production and Yield Components}

The impact of the experimental treatments on yield was assessed by harvesting two or three times a week (depending on the climatic conditions) all ripe tomatoes from 10 plants of each plot center square and recording their number and total fresh weight.

\subsection{Statistical Analysis}

The experiment was set as a randomized block design with four treatments and four replications per treatment. The impact of the different organic soil amendments on nitrogen nutrition and yield of tomato was estimated by applying single-factor ANOVA using the STATISTICA software package, version 12.0 for Windows. When ANOVA rendered a significant impact of the treatments on a measured parameter, the means were separated by applying the Duncan's multiple range test at $p<0.05$. Data are presented in graphs and tables as means of four replicates, whereas in the graphs the standard error of means is displayed to facilitate visual detection of significant differences.

\section{Results}

\subsection{Aboveground Legumes Biomass and Biological N Fixation}

The aboveground fresh (FB) and dry biomass (DB), the dry matter content, the total $\mathrm{N}$ concentration in dry biomass, the amount of $\mathrm{N}$ per unit of cultivated area, the percentage of $\mathrm{N}$ derived from the atmosphere (\% Ndfa), and the total amount of biologically fixed $\mathrm{N}$ did not differ significantly between the two legume treatments (LT and LT + OMWC) for both cowpea and faba bean (Table 3). Cowpea cultivated for green manuring produced aboveground biomass over $3100 \mathrm{~g} \mathrm{~m}^{-2}$, with a dry matter content of about $13 \%$. Moreover, the $\mathrm{N}$ derived from the atmosphere (Ndfa) was approximately $90 \%$, resulting in $140 \mathrm{~kg} \mathrm{ha}^{-1}$ of symbiotically fixed $\mathrm{N}$. On the other hand, the faba bean intercropped with tomato produced relatively low amounts of biomass and thus, despite the relatively high Ndfa $(80 \%)$, the BNF was barely $15 \mathrm{~kg} \mathrm{ha}^{-1}$. 
Table 3. Aboveground fresh (FB) and dry biomass (DB), dry matter content (DMC), total-N concentration in the aboveground dry biomass, total-N content per cultivated area unit, percentage of $\mathrm{N}$ derived from the atmosphere (Ndfa), and total amount of biologically fixed N (BNF) by cowpea used as green manure and by faba bean used as intercrop in an organic tomato crop.

\begin{tabular}{|c|c|c|c|c|c|c|c|}
\hline Treatment & $\begin{array}{c}\text { FB } \\
\left(\mathrm{g} \mathrm{m}^{-2}\right)\end{array}$ & $\begin{array}{c}\text { DMC } \\
(\%)\end{array}$ & $\begin{array}{c}\mathrm{DB} \\
\left(\mathrm{g} \mathrm{m}^{-2}\right)\end{array}$ & $\begin{array}{c}\text { Total-N } \\
\left(\mathrm{mg} \mathrm{g}^{-1}\right)\end{array}$ & $\begin{array}{l}\text { Total-N } \\
\left(\mathrm{g} \mathrm{m}^{-2}\right)\end{array}$ & $\begin{array}{c}\text { Ndfa } \\
(\%)\end{array}$ & $\begin{array}{c}\text { BNF } \\
\left(\mathrm{kg} \mathrm{ha}^{-1}\right)\end{array}$ \\
\hline \multicolumn{8}{|c|}{ Cowpea as green manure applied before the preceding tomato crop } \\
\hline LT & 3165 & 12.8 & 405 & 3.68 & 15.0 & 93.2 & 140 \\
\hline $\mathrm{LT}+\mathrm{OMWC}$ & 3128 & 13.4 & 417 & 3.65 & 15.2 & 88.0 & 134 \\
\hline Significance & ns & ns & ns & ns & ns & ns & ns \\
\hline \multicolumn{8}{|c|}{ Faba bean intercropping applied in the preceding tomato crop } \\
\hline LT & 650 & 8.21 & 53.6 & 3.53 & 1.89 & 77.8 & 14.7 \\
\hline $\mathrm{LT}+\mathrm{OMWC}$ & 630 & 8.56 & 54.1 & 3.44 & 1.86 & 80.2 & 15.0 \\
\hline Significance & ns & ns & ns & ns & ns & ns & ns \\
\hline
\end{tabular}

Means $(n=4)$; ns = not significant differences; LT: legume treatment; OMWC: olive-mill waste compost.

\subsection{Soil Measurements}

OMWC and FYM treatments resulted in higher levels of organic $\mathrm{C}$, total $\mathrm{N}$, and available $\mathrm{P}$ and $\mathrm{K}$ in the soil, compared to the application of legumes as a sole manure source. In addition, the FYM treatment increased the available soil $\mathrm{P}$ compared to the two compost treatments (Table 4).

Table 4. Impact of different organic fertilizer treatments on organic $\mathrm{C}$, total $\mathrm{N}$, and available $\mathrm{P}$ and $\mathrm{K}$ in soil after incorporation of organic materials in an experiment with organic greenhouse tomato.

\begin{tabular}{lcccc}
\hline Treatment & $\mathbf{C ~ ( \% )}$ & $\mathbf{N}(\mathbf{\%})$ & $\mathbf{P}\left(\mathbf{m g ~ k g}^{-\mathbf{1}}\right)$ & $\left.\mathbf{K}_{\mathbf{~ ( m g ~ k g ~}} \mathbf{- 1}\right)$ \\
\hline FYM & $2.71^{\mathrm{a}}$ & $0.22^{\mathrm{a}}$ & $167^{\mathrm{a}}$ & $756^{\mathrm{a}}$ \\
OMWC & $2.75^{\mathrm{a}}$ & $0.23^{\mathrm{a}}$ & $132^{\mathrm{b}}$ & $783^{\mathrm{a}}$ \\
LT & $2.01^{\mathrm{b}}$ & $0.20^{\mathrm{b}}$ & $112^{\mathrm{c}}$ & $556^{\mathrm{b}}$ \\
LT + OMWC & $2.81^{\mathrm{a}}$ & $0.24^{\mathrm{a}}$ & $130^{\mathrm{b}}$ & $763^{\mathrm{a}}$ \\
Significance & $* *$ & $* *$ & $* *$ & $* *$ \\
\hline
\end{tabular}

Means $(n=4)$ followed by different letters within each column indicate significant differences according to the Duncan's multiple range test $(p<0.05) ;{ }^{* *}$ significant at $p<0.01$. FYM: farmyard manure; LT: legume treatment; OMWC: olive-mill waste compost.

Prior to the incorporation of organic amendments, no difference in $\mathrm{NH}_{4}-\mathrm{N}$ concentrations was recorded between treatments, which ranged at low levels. After incorporation of the organic amendments to the soil, the FYM treatment exhibited significantly higher $\mathrm{NH}_{4}-\mathrm{N}$ levels in the soil compared to the other three treatments, in all subsequent measurements. In the other three treatments, the $\mathrm{NH}_{4}-\mathrm{N}$ levels were similar and below $4 \mathrm{mg} \mathrm{kg}^{-1}$ in all samplings (Figure 1).

The $\mathrm{NO}_{3}-\mathrm{N}$ concentrations exhibited significant differences between treatments before incorporation of organic materials to the soil in January 2018. Thus, in the FYM treatment, the soil $\mathrm{NO}_{3}-\mathrm{N}$ level was significantly higher compared to that found in the other three treatments. The lowest soil $\mathrm{NO}_{3}-\mathrm{N}$ concentration was recorded in the OMWC treatment and the difference to the two legume treatments was significant. These differences were consistently detected throughout the cropping period, i.e., after incorporation of organic amendments to the soil until termination of the experiment (Figure 2). 




Figure 1. The impact of organic materials in soil $\mathrm{NH}_{4}-\mathrm{N}$ concentrations. FYM: farmyard manure; LT: legume treatment; OMWC: olive-mill waste compost.

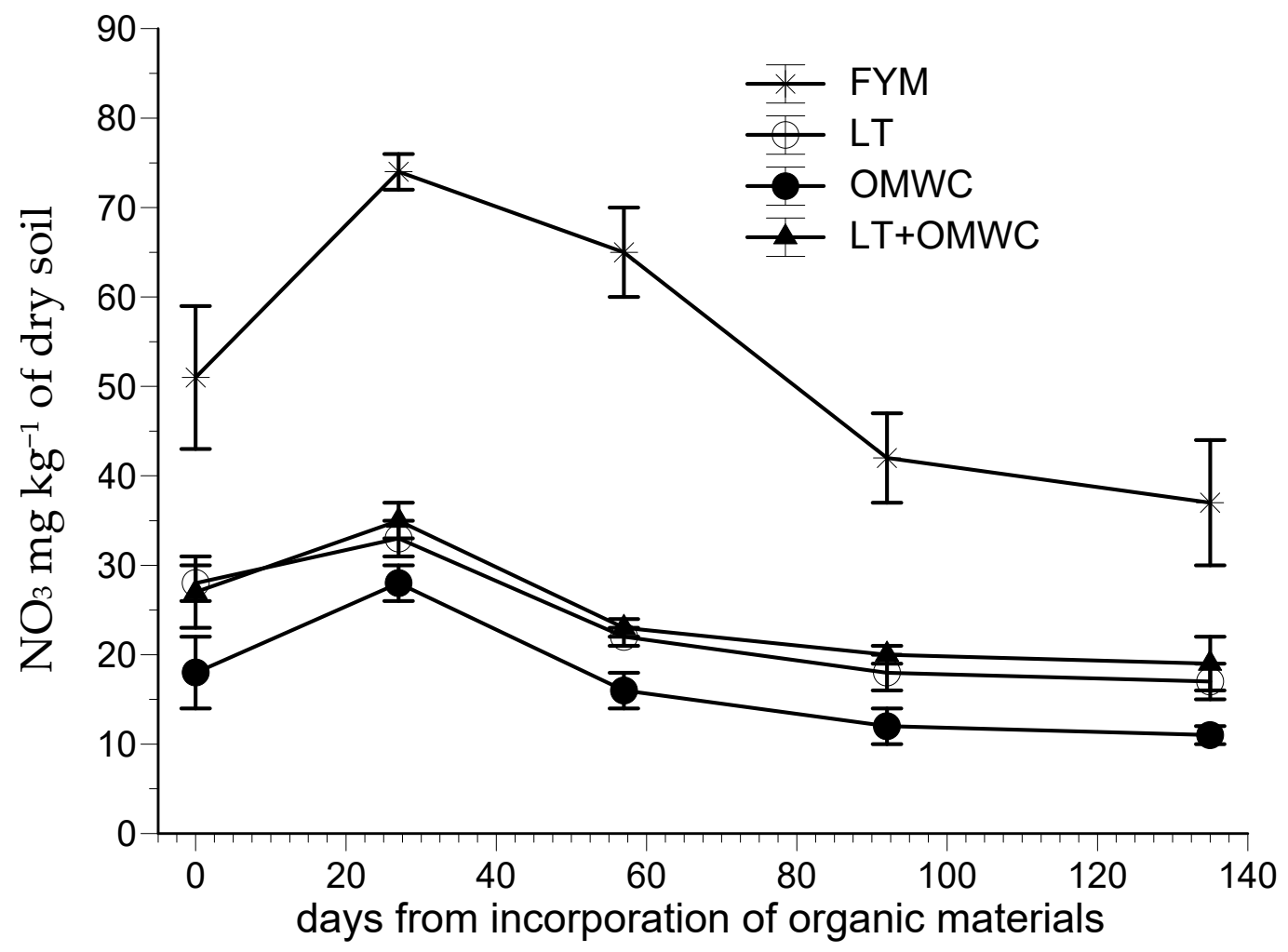

Figure 2. The impact of organic materials in soil $\mathrm{NO}_{3}-\mathrm{N}$ concentrations. FYM: farmyard manure; LT: legume treatment; OMWC: olive-mill waste compost. 


\subsection{Tomato Leaf Analysis}

As shown in Table 5, the total $\mathrm{N}$ concentration in the tomato leaves was significantly higher in the FYM treatment, while in the OMWC treatment it was lower, compared to the two LT. On the contrary, the P and K levels showed no statistical difference among treatments.

Table 5. Impact of different organic fertilization treatments on leaf N, P, K concentrations in organic greenhouse tomato.

\begin{tabular}{|c|c|c|c|}
\hline Treatment & $\begin{array}{c}\mathrm{N} \\
\mathrm{mg} \mathrm{g}^{-1}\end{array}$ & $\begin{array}{c}P \\
\mathrm{mg} \mathrm{g}^{-1}\end{array}$ & $\begin{array}{c}\mathrm{K} \\
\mathrm{mg} \mathrm{g}^{-1}\end{array}$ \\
\hline FYM & $19.3^{\mathrm{a}}$ & 2.03 & 52 \\
\hline OMWC & $13.1^{\mathrm{c}}$ & 2.27 & 48 \\
\hline LT & $14.7^{\mathrm{b}}$ & 2.14 & 51 \\
\hline $\mathrm{LT}+\mathrm{OMWC}$ & $14.8^{\mathrm{b}}$ & 2.09 & 47 \\
\hline Significance & * & ns & ns \\
\hline
\end{tabular}

Means $(n=4)$ followed by different letters within each column indicate significant differences according to the Duncan's multiple range test $(p<0.05) ;{ }^{*}$ significant at $p<0.05 ; \mathrm{ns}=$ not significant. FYM: farmyard manure; LT: legume treatment; OMWC: olive-mill waste compost.

\subsection{Tomato Production and Yield Components}

The tomato fruit yield was significantly affected by the different $\mathrm{N}$ fertilization treatments, as shown in Table 6. The FYM treatment showed the highest yield in tomato fruits, while the treatment with OMWC rendered the lowest yield. The difference was due, exclusively, to the average number of fruits per plant, whereas the mean fruit weight was similar in all treatments.

Table 6. Impact of different organic fertilization treatments on total yield, fruit number per plant, and mean fruit weight (MFW) in an organic greenhouse tomato.

\begin{tabular}{lccc}
\hline Treatment & $\begin{array}{c}\text { Yield } \\
\left(\mathbf{g ~ m ~}^{-\mathbf{2}} \mathbf{)}\right.\end{array}$ & $\begin{array}{c}\text { Fruit } \\
\left.\text { (No Plant }^{-\mathbf{1}}\right)\end{array}$ & $\begin{array}{c}\text { MFW } \\
\text { (g Fruit }^{-1)}\end{array}$ \\
\hline FYM & $7732^{\mathrm{a}}$ & $19.4^{\mathrm{a}}$ & 186 \\
OMWC & $5048^{\mathrm{c}}$ & $13.1^{\mathrm{c}}$ & 180 \\
LT & $6216^{\mathrm{b}}$ & $15.2^{\mathrm{b}}$ & 191 \\
LT + OMWC & $6413^{\mathrm{b}}$ & $15.8^{\mathrm{b}}$ & 190 \\
Significance of & $* *$ & $* * *$ & $\mathrm{~ns}$ \\
differences & & &
\end{tabular}

Means $(n=4)$ followed by different letters within each column indicate significant differences according to the Duncan's multiple range test: ${ }^{* *}, * * *$ significant at $p<0.01$ and $p<0.001$, respectively; ns $=$ not significant. FYM: farmyard manure; LT: legume treatment; OMWC: olive-mill waste compost.

\section{Discussion}

\subsection{Aboveground Legumes Biomass and Biological N Fixation}

The amount of symbiotically fixed $\mathrm{N}_{2}$ by a legume crop that is provided to the soil after incorporation of the fresh shoot biomass to the soil depends on many factors and can range from 17 to $200 \mathrm{~kg}$, according to relevant reports of many researchers [12,32-34]. In this study, the biomass produced by cowpea in the 2-month summer crop was relatively high. In addition, the \%Ndfa in the shoots of cowpea was much higher than that reported by Peoples et al. [35], probably due to the low level of mineral $\mathrm{N}$ contained in the soil in the current study. As a result, a large amount of symbiotically fixed $\mathrm{N}_{2}\left(140 \mathrm{~kg} \mathrm{ha}^{-1}\right)$ was provided to the soil through green manuring with cowpea, which is slightly lower than the maximum amount of $\mathrm{N}\left(170 \mathrm{~kg} \mathrm{ha}^{-1}\right)$ allowed to be applied by animal manure to organic crops according to the relevant Regulation (EC) 889/2008.

The $\%$ Ndfa in the shoot of faba bean was also high compared to those reported in the literature [21,35]. On the other hand, faba bean as intercrop did not produce considerable amounts of shoot biomass. This was probably due to the interception of solar radiation 
by the upper part of the tomato canopy, as faba bean was sown 85 days after tomato transplanting, while the sunshine was already limited due to the short day and the overcast sky in Autumn-Winter season. In addition, the sowing density of faba bean was low, particularly 10.67 seeds $\mathrm{m}^{-2}$ as the available cultivation area for an intercrop was limited by the presence of the tomato crop. Thus, despite the high Ndfa values, BNF by faba bean ranged at low levels in both treatments, which did not exceed $15 \mathrm{~kg}^{\text {ha }}{ }^{-1}$.

\subsection{Soil Measures}

The impact of green manure on total soil $\mathrm{N}$ was significantly lower than that of manure or compost. As reported by Peoples et al. [36], the effect of green manuring on the total $\mathrm{N}$ of the soil is not always easy to detect. Also, according to Sainju et al. [37], repeated applications of green manure are necessary for a significant increase of soil $\mathrm{C}$ and organic $\mathrm{N}$ through a cumulative effect.

As anticipated, the lowest values of available soil $\mathrm{P}$ and $\mathrm{K}$ were recorded in the treatment with sole green manure, as no other nutrients than the symbiotically fixed $\mathrm{N}$ were provided to the soil. Nevertheless, the $\mathrm{P}$ and $\mathrm{K}$ concentrations in all treatments in both experiments were sufficient for tomato cultivation, according to Gianquinto et al. [38] and Sainju et al. [39].

The availability of $\mathrm{N}$ in organic farming does not depend only on total $\mathrm{N}$ provided to the soil but also on the rate of $\mathrm{N}$ net mineralization, which provides plant-available $\mathrm{N}$ to plants. The consistently higher concentrations of $\mathrm{NH}_{4}-\mathrm{N}$ in the FYM treatment in all sampling dates compared to all other treatments obviously reflects higher net mineralization rates in this treatment. Nevertheless, the $\mathrm{NH}_{4}-\mathrm{N}$ concentrations were always below $10 \mathrm{mg} \mathrm{kg}^{-1}$, as expected, because in well-aerated soils with neutral $\mathrm{pH}$ and sufficient microbial activity, the nitrification process is rapid [40-42].

The treatment with FYM resulted in $\mathrm{NO}_{3}-\mathrm{N}$ values within the sufficient range for tomato cultivation $[39,43]$ during the first two sampling dates after organic matter incorporation. However, in the next sampling (75 days after transplanting), the $\mathrm{NO}_{3}-\mathrm{N}$ concentration decreased to insufficient levels. In the other three treatments, with legumes or compost or a combination of both, the $\mathrm{NO}_{3}-\mathrm{N}$ concentration ranged lower than the sufficient level in all sampling dates. In the treatment with sole compost, consistently lower $\mathrm{NO}_{3}-\mathrm{N}$ values were recorded, compared to the treatments with legumes, indicating that the mineralization rate of compost was substantially lower than those of legume biomass and FYM $[44,45]$.

\subsection{Tomato Growth and Yield Components}

In this experiment, the leaf total $\mathrm{N}$ concentrations were in all treatments lower than those suggested in the literature for tomato, which range from 30 to $50 \mathrm{mg} \mathrm{g}^{-1}$ [38,46-48]. These results are in agreement with the insufficient concentrations of soil inorganic $\mathrm{N}$ during most or the entire cropping period. As a result, symptoms of $\mathrm{N}$ deficiency, i.e., plants with thin stems and light green leaves [39,49], appeared in all treatments. In the FYM treatment, in which the soil was adequately supplied with mineral $\mathrm{N}$ [38,39] for about 2.5 months after crop establishment, the $\mathrm{N}$ deficiency symptoms were observed much later than in the other three treatments. However, when the level of plant available $\mathrm{N}$ in the FYM treatment decreased to insufficient levels, the plants showed symptoms of $\mathrm{N}$ deficiency in this treatment as well. The total leaf $\mathrm{N}$ in the FYM treatment was significantly higher than in the other three treatments, reflecting the higher $\mathrm{N}$ availability in the soil. The values of $\mathrm{P}$ and $\mathrm{K}$ in the leaves were within the optimal range $[38,39]$ in all treatments, reflecting the adequacy of these nutrient elements in the soil.

Furthermore, the different soil amendments imposed significant differences in the tomato fruit yield, which are attributed to the different concentrations of inorganic $\mathrm{N}$ in the soil [50-52]. Thus, the FYM treatment showed the highest yield, whereas in the two legume treatments the yield was similar, but higher than in the treatment with sole compost application. The low yield performance in the sole compost treatment, despite the similarly 
high amount of organic $\mathrm{N}$ provided to the soil by this treatment compared to the other treatments, is ascribed to the low rate of $\mathrm{N}$ mineralization in the compost. This finding suggests that the benefits of compost application in organic crops with respect to $\mathrm{N}$ supply to the plants should be anticipated in the long term and not in the crop established shortly after its incorporation into the soil.

\section{Conclusions}

This study confirms that green manuring with legumes and particularly cowpea can contribute a significant amount of $\mathrm{N}$ to the next organic tomato crop, through biological $\mathrm{N}_{2}$-fixation processes. This amount may be slightly lower than the maximum amount of $\mathrm{N}$ that can be applied through animal manure in organic farming according to current EU regulations. In contrast, faba bean as an intercrop in a greenhouse tomato crop did not yield a significant amount of biomass and therefore did not supply the next tomato crop with sufficient amounts of $\mathrm{N}$, mainly due to the limitations governing the sowing density, but also due to insufficient interception of solar radiation, as tomato limits the exposure of the faba bean plants to the sun, especially during the autumn-winter season. Application of compost in organic greenhouse tomato provides limited amounts of plant-available $\mathrm{N}$ to the crop planted after incorporation of the compost to the soil due to low $\mathrm{N}$ mineralization rates, although it may be beneficial for subsequent tomato crops. Green manuring with legumes, alone or in combination with compost, increased the yield of organic tomato compared to sole compost. However, application of free-range cattle manure (FYM) seems to be the most effective strategy for supplying tomato with inorganic $\mathrm{N}$, partly because of rapid N mineralization. Nevertheless, sole supply of FYM is not suggested in longterm greenhouse tomato crops because, due to rapid N mineralization, the FYM provides sufficient amounts of mineral $\mathrm{N}$ to the crop only for a short period after its incorporation to the soil. In the current study, this period did not exceed 3 months.

Author Contributions: Conceptualization, A.G., D.S. and G.N.; Data curation, A.G., G.N., D.Y., P.B., I.C.K., G.P. and D.S.; Formal analysis, A.G., D.Y., P.B., I.T., G.P. and D.S.; Funding acquisition, G.N. and D.S.; Investigation, A.G., G.N., D.S., I.T. and D.S.; Methodology, A.G., G.N., D.Y., P.B., I.C.K., I.T., G.P. and D.S.; Project administration, G.N. and D.S.; Resources, G.N. and D.S.; Software, A.G., P.B., I.C.K., I.T., G.P. and D.S.; Supervision, D.S.; Validation, A.G., G.N., I.C.K., I.T., G.P. and D.S.; Visualization, A.G. and G.N.; Writing—original draft, A.G., G.N. and D.S.; Writing-review \& editing, A.G., G.N., D.Y., I.C.K., I.T., G.P. and D.S. All authors have read and agreed to the published version of the manuscript.

Funding: This research was funded by the European Commission within the HORIZON2020 project 'TOMRES-A novel and integrated approach to increase multiple combined stress tolerance in plants using tomato as a model' (Grant Agreement 727929).

Institutional Review Board Statement: Not applicable.

Informed Consent Statement: Not applicable.

Data Availability Statement: Not applicable.

Conflicts of Interest: The authors declare no conflict of interest.

\section{References}

1. Willer, H.; Lernoud, J. The World of Organic Agriculture: Statistics and Emerging Trends 2019; Research Institute of Organic Agriculture FiBL: Frick, Switzerland; IFOAM Organics International: Bonn, Germany, 2019; pp. 1-336.

2. Bravo, C.P.; Cordts, A.; Schulze-Ehlers, B.; Spiller, A. Assessing determinants of organic food consumption using data from the German National Nutrition Survey II. Food Qual. Prefer. 2013, 28, 60-70. [CrossRef]

3. Dimitri, C.; Dettmann, R.L. Organic food consumers: What do we really know about them? Br. Food J. 2012, 114, 1157-1183. [CrossRef]

4. Woodward, L. Science, Research and Organic Farming. In The Science Beneath Organic Production; John Wiley \& Sons: Hoboken, NJ, USA, 2019; pp. 25-32. ISBN 978-1-119-55461-5.

5. Kremen, C.; Miles, A. Ecosystem services in biologically diversified versus conventional farming systems: Benefits, externalities, and trade-offs. Ecol. Soc. 2012, 17, 1-25. [CrossRef] 
6. Watson, C.A.; Atkinson, D.; Gosling, P.; Jackson, L.R.; Rayns, F.W. Managing soil fertility in organic farming systems. Soil Use Manag. 2002, 18, 239-247. [CrossRef]

7. Stockdale, E.A.; Edwards, T.C.; Watson, C.A. Soil health and its management for organic farming. In The Science Beneath Organic Production; John Wiley \& Sons: Hoboken, NJ, USA, 2019; pp. 45-77. [CrossRef]

8. Berry, P.M.; Stockdale, E.A.; Sylvester-Bradley, R.; Philipps, L.; Smith, K.A.; Lord, E.I.; Watson, C.A.; Fortune, S. N, P and K budgets for crop rotations on nine organic farms in the UK. Soil Use Manag. 2003, 19, 112-118. [CrossRef]

9. Bustamante, S.C.; Hartz, T. Nitrogen management in organic processing tomato production: Nitrogen sufficiency prediction through early-season soil and plant monitoring. HortScience 2015, 50, 1055-1063. [CrossRef]

10. Clark, M.; Horwath, W.R.; Shennan, C.; Scow, K.M.; Lantni, W.; Ferris, H. Nitrogen, weeds and water as yield-limiting factors in conventional, low-input, and organic tomato systems. Agric. Ecosyst. Environ. 1999, 73, 257-270. [CrossRef]

11. Tittarelli, F.; Bath, B.; Ceglie, F.G.; del Carmen Garcia, M.; Möller, K.; Reents, H.J.; Védie, H.; Voogt, W. Soil Fertility Management in Organic Greenhouses in Europe; BioGreenhouse: Wageningen, The Netherlands, 2016; p. 48. ISBN 9789462575363.

12. Gatsios, A.; Ntatsi, G.; Celi, L.; Said-Pullicino, D.; Tampakaki, A.; Giannakou, I.; Savvas, D. Nitrogen nutrition optimization in organic greenhouse tomato through the use of legume plants as green manure or intercrops. Agronomy 2019, 9, 766. [CrossRef]

13. The Commission of the European Communities. Commission Regulation (EC) 889 Commission Regulation (EC) No 889/2008. Off. J. Eur. Union 2008, 250, 1-84.

14. Colla, G.; Mitchell, J.P.; Poudel, D.D.; Temple, S.R. Changes of tomato yield and fruit elemental composition in conventional, low input, and organic systems. J. Sustain. Agric. 2002, 20, 53-67. [CrossRef]

15. Voogt, W.; De Visser, P.; Van Winkel, A.; Cuijpers, W.; Van De Burgt, G. Nutrient management in organic greenhouse production: Navigation between constraints. Acta Hortic. 2011, 915, 75-82. [CrossRef]

16. Heuvelink, E. Tomatoes, 2nd ed.; CABI: Boston, MA, USA, 2018; Volume 27, ISBN 178-064-193-1.

17. Chowdhury, A.K.M.M.B.; Akratos, C.; Vayenas, D.; Pavlou, S. Olive mill waste composting: A review. Int. Biodeterior. Biodegrad. 2013, 85, 108-119. [CrossRef]

18. Lenzi, A.; Antichi, D.; Bigongiali, F.; Mazzoncini, M.; Migliorini, P.; Tesi, R. Effect of different cover crops on organic tomato production. Renew. Agric. Food Syst. 2009, 24, 92-101. [CrossRef]

19. Fatima, T.; Teasdale, J.R.; Bunce, J.; Mattoo, A.K. Tomato response to legume cover crop and nitrogen: Differing enhancement patterns of fruit yield, photosynthesis and gene expression. Funct. Plant Biol. 2012, 39, 246-254. [CrossRef] [PubMed]

20. Araki, H. Tomato production with cover crops in greenhouse. In Alternative Crops and Cropping Systems; Intehopen: London, UK, 2016; p. 87. [CrossRef]

21. Denton, M.D.; Phillips, A.L.; Peoples, M.B.; Pearce, D.J.; Swan, A.D.; Mele, P.M.; Brockwell, J. Legume inoculant application methods: Effects on nodulation patterns, nitrogen fixation, crop growth and yield in narrow-leaf lupin and faba bean. Plant Soil 2017, 419, 25-39. [CrossRef]

22. Tampakaki, A.P.; Fotiadis, C.T.; Ntatsi, G.; Savvas, D. Phylogenetic multilocus sequence analysis of indigenous slow-growing rhizobia nodulating cowpea (Vigna unguiculata L.) in Greece. Syst. Appl. Microbiol. 2017, 40, 179-189. [CrossRef] [PubMed]

23. Efstathiadou, E.; Savvas, D.; Tampakaki, A.P. Genetic diversity and phylogeny of indigenous rhizobia nodulating faba bean (Vicia faba L.) in Greece. Syst. Appl. Microbiol. 2020, 43, 126149. [CrossRef]

24. Unkovich, M.J.; Herridge, D.; Peoples, M.; Cadish, G.; Boddey, R.; Giller, K.; Alves, B.; Chalk, P. 15N natural abundance method. In Measuring Plant Associated Nitrogen Fixation in Agricultural Systems; ACIAR: Canberra, Australia, 2008 ; pp. 131-162. ISBN 978-1-921531-26-2.

25. Ntatsi, G.; Karkanis, A.; Yfantopoulos, D.; Pappa, V.; Konosonoka, I.H.; Travlos, I.; Bilalis, D.; Bebeli, P.; Savvas, D. Evaluation of the field performance, nitrogen fixation efficiency and competitive ability of pea landraces grown under organic and conventional farming systems. Arch. Agron. Soil Sci. 2018, 65, 294-307. [CrossRef]

26. Bedard-Haughn, A.; Van Groenigen, J.W.; van Kessel, C. Tracing $15 \mathrm{~N}$ through landscapes: Potential uses and precautions. J. Hydrol. 2003, 272, 175-190. [CrossRef]

27. Collino, D.J.; Salvagiotti, F.; Perticari, A.; Piccinetti, C.; Ovando, G.; Urquiaga, S.; Racca, R.W. Biological nitrogen fixation in soybean in Argentina: Relationships with crop, soil, and meteorological factors. Plant Soil 2015, 392, 239-252. [CrossRef]

28. Miller, R.O.; Gavlak, R.; Horneck, D. Soil, plant and water reference methods for the western region. In WREP-125, 4th ed.; Colorado State University: Fort Collins, CO, USA, 2013; p. 155.

29. Keeney, D.R.; Nelson, D.W. Nitrogen-Inorganic Forms. Methods Soil Anal. 1983, 9, 643-698.

30. Olsen, S.R. Estimation of Available Phosphorus in Soils by Extraction with Sodium Bicarbonate; US Department of Agriculture: Washington, DC, USA, 1954; p. 939.

31. Murphy, J.; Riley, J.P. A modified single solution method for the determination of phosphate in natural waters. Anal. Chim. Acta 1962, 27, 31-36. [CrossRef]

32. Cavigelli, M.A.; Teasdale, J.R.; Conklin, A.E. Long-term agronomic performance of organic and conventional field crops in the Mid-Atlantic region. Agron. J. 2008, 100, 785-794. [CrossRef]

33. Rochester, I.J.; Peoples, M.B.; Constable, G.A.; Gault, R.R. Faba beans and other legumes add nitrogen to irrigated cotton cropping systems. Aust. J. Exp. Agric. 1998, 38, 253-260. [CrossRef]

34. Reinbott, T.M.; Conley, S.; Blevins, D.G. No-tillage corn and grain sorghum response to cover crop and nitrogen fertilization. Agron. J. 2004, 96, 1158-1163. [CrossRef] 
35. Peoples, M.B.; Brockwell, J.; Herridge, D.F.; Rochester, I.J.; Alves, B.J.R.; Urquiaga, S.; Boddey, R.M.; Dakora, F.D.; Bhattarai, S.; Maskey, S.L.; et al. The contributions of nitrogen-fixing crop legumes to the productivity of agricultural systems. Symbiosis 2009, 48, 1-17. [CrossRef]

36. Peoples, M.B.; Herridge, D.; Ladha, J. Biological nitrogen fixation: An efficient source of nitrogen for sustainable agricultural production? Plant Soil 1995, 174, 3-28. [CrossRef]

37. Sainju, U.; Singh, B.; Whitehead, W. Comparison of the effects of cover crops and nitrogen fertilization on tomato yield, root growth, and soil properties. Sci. Hortic. 2001, 91, 201-214. [CrossRef]

38. Gianquinto, G.; Muñoz, P.; Pardossi, A.; Ramazzotti, S.; Savvas, D. Soil fertility and plant nutrition. In Good Agricultural Practices for Greenhouse Vegetable Crops. Principles for Mediterranean Climate Areas; FAO: Rome, Italy, 2013; pp. 205-269. ISBN 9789251076491.

39. Sainju, U.M.; Dris, R.; Singh, B. Mineral nutrition of tomato. Food Agric. Environ. 2003, 1, 176-184.

40. Li, Z.; Zeng, Z.; Tian, D.; Wang, J.; Fu, Z.; Zhang, F.; Zhang, R.; Chen, W.; Luo, Y.; Niu, S. Global patterns and controlling factors of soil nitrification rate. Glob. Chang. Biol. 2020, 26, 4147-4157. [CrossRef]

41. Barnard, R.; Leadley, P.W.; A Hungate, B. Global change, nitrification, and denitrification: A review. Glob. Biogeochem. Cycles 2005, 19, 1-13. [CrossRef]

42. Pandey, A.; Li, F.; Askegaard, M.; Rasmussen, I.A.; Olesen, J.E. Nitrogen balances in organic and conventional arable crop rotations and their relations to nitrogen yield and nitrate leaching losses. Agric. Ecosyst. Environ. 2018, 265, 350-362. [CrossRef]

43. Van Eysinga, J.R. Fertilization of Tomatoes with Nitrogen; Pudoc: Wageningen, The Netherlands, 1971; p. 17.

44. Baldwin, K.R. Soil Fertility on Organic Farms; North Carolina Cooperative Extension: Raleigh, NC, USA, 2006 ; pp. 1-32.

45. Nair, A.; Delate, K. Composting, crop rotation, and cover crop practices in organic vegetable production. In Sustainable Development and Biodiversity; Springer: Berlin/Heidelberg, Germany, 2016; pp. 231-257.

46. Bryson, G.M.; Barker, A.V. Determination of optimal fertilizer concentration range for tomatoes grown in peat-based medium. Commun. Soil Sci. Plant Anal. 2002, 33, 759-777. [CrossRef]

47. Mills, H.A.; Jones, J.B., Jr. Plant Analysis Handbook II: A Practical Sampling, Preparation, Analysis, and Interpretation Guide; MicroMacro Publishing: Athens, GA, USA, 1996; ISBN 1878148052.

48. Hanan, J.J. Greenhouses: Advanced Technology for Protected Horticulture; CRC Press: Boca Raton, FL, USA, 1997 ; p. 684. ISBN 0849316987.

49. Papadopoulos, A.P. Growing Greenhouse Tomatoes in Soil and in Soilless Media; Communications Branch, Agriculture Canada: Ottawa, ON, Canada, 1991; p. 79. ISBN 0662188594.

50. Márquez-Quiroz, C.; Sanchez-Chavez, E.; De La Cruz-Lázaro, E.; Osorio-Osorio, R.; López-Espinosa, S.T. Nitrogen metabolism and tomato yield in response to organic fertilization. Commun. Soil Sci. Plant Anal. 2015, 46, 2774-2786. [CrossRef]

51. Heeb, A.; Lundegårdh, B.; Ericsson, T.; Savage, G.P. Effects of nitrate-, ammonium-, and organic-nitrogen-based fertilizers on growth and yield of tomatoes. J. Plant Nutr. Soil Sci. 2005, 168, 123-129. [CrossRef]

52. Hernández, V.; Hellín, P.; Fenoll, J.; Flores, P. Impact of nitrogen supply limitation on tomato fruit composition. Sci. Hortic. 2020, 264, 109173. [CrossRef] 